\title{
THE UNFORGIVING: REFLECTIONS ON THE RESISTANCE TO FORGIVENESS AFTER ATROCITY
}

\author{
THOMAS BRUDHOLM
}

VALÉRIE ROSOUX*

INTRODUCTION

Enraged by calls upon the Nazi victims to forgive, Vladimir Jankélévitch once asserted that forgiveness "died" in the Nazi extermination camps. ${ }^{1}$ If the murderers wished for forgiveness they should go and ask the children who were burned alive. If the survivor had a moral task to consider, it was the unending preservation of a resentful and unreconciled memory of those who were murdered. ${ }^{2}$ At about the same time, in the 1960s, Hannah Arendt took notice of widespread German sentiments about the possibility of immediate reconciliation. According to Arendt, the sentiments revealed the degree to which the systematic mendacity - the escalating self-deception-of the Third Reich had been internalized by the people. ${ }^{3}$

Today, the belief in the possibility and value of forgiveness and reconciliation is in considerable vogue. ${ }^{4}$ Jankélévitch and Arendt responded to

Copyright () 2009 by Thomas Brudholm \& Valérie Rosoux.

This Article is also available at http://www.law.duke.edu/journals/lcp.

* Thomas Brudholm is Associate Professor at the University of Copenhagen. He wishes to thank the Danish Research Council for the Humanities for funding to write the article. Valérie Rosoux is Research Associate at the Belgian National Fund for Scientific Research (FNRS). She teaches International Negotiation at the Catholic University of Louvain. The authors wish to thank, Laetitia Bucaille, Ariel Colonomos, Elise Féron, Pierre Hassner, Margaret Walker, and William Zartman, for helpful comments and stimulating discussions. Also, thanks to the encouraging and meticulous editors and reviewers of this issue.

1. Vladimir Jankélévitch, Should We Pardon Them?, 22 CRITICAL INQUIRY 552, 567 (1996).

2. Id. at $565-72$.

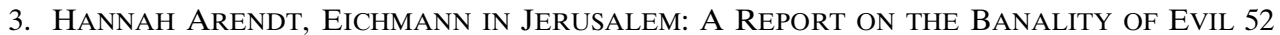
(1978).

4. There is no unanimous conception of forgiveness, and the uses and understandings of the term after atrocity display a considerable range of conflicting approaches. For interesting recent philosophical responses to the question of the nature of forgiveness, see generally CHARLES GRISWOLD, FORGIVENESS: A PHILOSOPHICAL EXPLORATION (2008) (using both ancient and modern philosophy to examine forgiveness in both its interpersonal and political contexts, as well as its relation to our aspiration for reconciliation), and MARGARET WALKER, MORAL REPAIR (2006) (using realistic examples of personal betrayal and political violence to analyze how moral bonds are damaged by serious wrongs and what must be done to repair the damage). 
popular sentiments, but within the last two decades, the advocacy of forgiveness has also become the business of nongovernmental organizations (NGOs), health-care workers, and conflict mediators. ${ }^{5}$ Forgiveness is encouraged by religious leaders chairing truth and reconciliation commissions, as well as by political leaders publicly pleading with victims to forgive. ${ }^{6}$ Yet, more than that, the interest in the topic has gained an explosive momentum among scholars around the world. Forgiving is examined as a personal virtue, as a rational and therapeutic response, and as a necessary condition for social and political reconciliation through the overcoming of emotions like resentment and vindictiveness. ${ }^{7}$ An increasing number of critical studies are being published; but the mainstay of the literature on the practice and value of forgiveness as a means to reconciliation has been marked by laudatory approaches that take for granted that forgiveness is morally, politically, and therapeutically superior to resentment and other "negative" attitudes.

The need for more critical reflection arises, not the least, from attention to current public appraisals of forgiveness in so-called post-conflict societies. In places like Rwanda, Sierra Leone, Liberia, and South Africa, religious leaders publicly praise or recommend unconditional forgiveness, or urge people to marvel at the wish of a victim that she may be forgiven by the man who injured her grievously and killed others.' State officials help ex-perpetrators post prefabricated letters that mimic what could perhaps have been a genuinely contrite sign of remorse and repentance. ${ }^{10}$ According to its advocates, forgiveness is the best or the only path to personal as well as social healing and reconciliation. To opt for forgiveness is, or so it seems, to side not only with virtue but also with prudence. Not to forgive is ultimately a sign of a regrettable

5. Even though the role of NGOs, health-care workers, and mediators has not significantly changed, the emphasis put on forgiveness seems to be quite recent. See PENAL REFORM INTERNATIONAL, GACACA RESEARCH REPORT NO.7: INTEGRATED REPORT ON THE PILOT PHASE, JANUARY 2002-DECEMBER 2004 (2005), http://www.penalreform.org/integrated-report-on-gacacaresearch-and-monitoring-pilot-phase-january-2002-december.html; see also S. Lefranc, Du droit à la paix. La circulation des techniques internationales de pacification par le bas, 174 ACTES DE LA RECHERCHE EN SCIENCES SOCIALES 48-67 (2008) (Fr.).

6. As the chairman of the Truth and Reconciliation Commission in Sierra Leone, Bishop J.C. Humper, put in his foreword to the report of the commission, "Learning to forgive those who have wronged us is the first step we can take towards healing our traumatised nation." J.C. Humper, Foreword to 1 SIERRA LEONE TRUTH AND RECONCILIATION COMMISSION, WitNESS TO TRUTH 2, 3 (2004).

7. See, e.g., Exploring Forgiveness (R.D. Enright \& J. North eds., 1998); J. MurPHY, GetTing Even: Forgiveness AND Its Limits (2003); A. SCHAAP, Political RECONCILIATION (2005).

8. For similar assessments, see Daniel Philpott, Religion, Reconciliation, and Transitional Justice: The State of the Field (Soc. Sci. Research Council, Working Paper, 2007), available at http://programs.ssrc.org/religion/reconciliation.pdf; see also, Sharon Lamb, Forgiveness, Women, and Responsibility to the Group, 5 J. HUM. RTS. 45, 45-60 (2006).

9. For the praise of unconditional forgiveness, see Humper, supra note 6. For the praise of the wish of a victim to be forgiven, see D. TUTU, No FUTURE WITHOUT FORGIVENESS 147 (1999).

10. Esther MujaWAyo \& SOUAd Belhaddad, LA Fleur DE StÉPHANIE: ENTRE RÉCONCILIATION ET DÉNI 128 (2006) (Fr.) (translation by authors). 
lack of rationality or moral virtue. Perhaps this is one reason why victims can be encouraged or expected to forgive even when the plea for forgiveness seems both cheap and calculated. In Liberia, an exceptionally brutal, former Liberian rebel leader accompanied his confessions of a horrible and vast catalogue of crimes not just with a plea for forgiveness, but also with a counsel of forgiveness as "the right way to go" and the key to national healing. ${ }^{11}$ The apparent ease and self-confidence with which even mass murderers can request, counsel, or expect forgiveness is bewildering to the observer, but it can be unfathomable to the survivor. As Francine, a survivor of the carnage in Rwanda, responds to the very idea of being approached by an ex-genocidaire asking for forgiveness, "[I]f he has worked at killing for a whole month, even on Sundays, whatever can he hope to be forgiven for?" This expression of a sense of limits is precisely what is absent when forgiveness gets "boosted" as an unqualified virtue or sociopolitical good.

From the perspective adopted in this article, the trends and cases mentioned above substantiate the observation that we live in a time in which the virtue of forgiveness risks becoming "distorted and cheapened by various movements that advocate it in a hasty and uncritical way." 13 There is a strong need for a sustained and extensive ethical reflection on the advocacy and practice of forgiveness, not the least in the context of transitional justice and reconciliation. This article is intended to address just one small part of this more comprehensive undertaking. More precisely, we would like to bring more nuance to common conceptions of unforgiving victims and the resistance or refusal to forgive.

Advocates of forgiveness naturally tend to privilege "forgivers" as examples of the kind of moral character, humane generosity, civic virtue, or sheer prudence that is needed if the goal of reconciliation is to come closer. Those who say they will not forgive might be mentioned, admonished, or received with expressions of understanding or even respect, but their motivations and reflections are seldom seriously investigated. Indeed, when forgiveness is boosted as a panacea and an absolute virtue, unforgiveness takes on the spectre of a morally impossible position: if the unforgiving survivors understood more about the background of the perpetrators, or about what ideals and values really count; if they did not confuse forgetting with forgiving; if they were more capable of managing their anger; if they thought more rationally about their own good or the good of the nation, then they would try to forgive or let go of their resentment and engage more constructively in the process of

11. See Jonathan Paye-Layleh, I Ate Children's Hearts, Ex-Rebel Says, BBC NEws, Jan. 22, 2008, http://news.bbc.co.uk/2/hi/africa/7200101.stm (reporting on Milton Blahyi's confession and request for forgiveness).

12. Jean Hatzfeld, Machete Season: The Killers in Rwanda Speak 196 (Linda Coverdale, trans., Picador 2006) (2003).

13. Jeffrie Murphy, Foreword to Thomas Brudholm, RESEnTMENT's Virtue: JeAn AMÉRY AND THE REFUSAL TO FORGIVE, at ix (2008). 
reconciliation. Relentless, backward-looking resentment must be the sign of some kind of moral failure or irrationality on behalf of its holder. ${ }^{14}$

In order to complement and challenge given conceptions of unforgiving victims, this article considers several actual examples of resistance with particular concentration on the reflections of two genocide survivors, namely Jean Améry and Esther Mujawayo. This focus on the voices of two individual survivors is deliberate and tied to the very nature of the problem being addressed here. By drawing on the reflections of unforgiving victims themselves, we wish to challenge the way in which they are represented by third-party advocates of forgiveness. And by attending to the voices of particular individuals, we hope to defy stereotypical or purely theoretical conceptions of "the" unforgiving victim or "the" refusal to forgive. ${ }^{15}$

\section{II}

\section{THE MORALITY OF RESISTANCE: JEAN AMÉRY}

Jean Améry was born in Austria as Hans Maier in 1912. His father was an assimilated Jew and his mother a Catholic. With the rise of the Nazi regime, Maier's Jewish ancestry became potentially fatal, and in December 1938 he fled to Belgium and joined the resistance. He was soon caught, tortured by the Gestapo, and sent to a number of concentration and extermination camps, including Auschwitz. Upon liberation from Bergen-Belsen, Maier returned to Brussels, and in 1955 he began publishing under the French anagram Jean Améry. Améry used his own life and experiences as the object of literary experimentation or philosophical elucidation. Among his later writings, one finds works on suicide, and the proximity between his life and his work was, sadly, also evident in them: in 1978, Améry took his own life in a hotel room in Salzburg.

Améry's collected works span nine thick volumes, but his most influential work probably remains Jenseits von Schuld und Sühne (Beyond Guilt and Atonement), which was published in $1965 .^{16}$ The book consists of a series of essays in which Améry tries to articulate philosophically the experiences and post-war situation - the conditio inhumana-of the surviving Nazi victim. In spite of declarations that his intent was only to describe, the essays also testify

14. For an extensive examination of this aspect of the advocacy of forgiveness, see BRUDHOLM, supra note 13, at 21-62 (reviewing advocacy of forgiveness by The Truth and Reconciliation Commission of South Africa). For an examination of ways in which advocating forgiveness risks jeopardizing the needs and autonomy of the victims, see generally Thomas Brudholm, On the Advocacy of Forgiveness After Mass Atrocities, in THE RELIGIOUS IN RESPONSES TO MASS ATROCITY: INTERDISCIPLINARY PERSPECTIVES 124 (Thomas Brudholm \& Thomas Cushman eds., 2009) [hereinafter Brudholm, Forgiveness after Mass Atrocities].

15. As we are featuring the written work of two victims who are extraordinarily lucid in explaining their resistance, it should be mentioned that we do not pretend to represent "the victims" as a general category, but rather to illustrate the possibility of an often-neglected normative stance.

16. The English translation is JEAN AMÉRY, AT THE MIND's LIMITS: CONTEMPLATIONS BY A SuRVivor ON AUsChWitz AND ITS REAlities (Sidney Rosenfeld \& Stella P. Rosenfeld trans., 1980). 
to a wish that they would be a cause of change. That is, the essays were not only the attempt of a surviving victim to examine his own ruined life, but also a revolt against the way German society dealt with its past. During the first couple of decades following 1945, a desire among Germans to "turn the page" or "forgive and forget" was foremost. For Améry this was morally impossible, and with Beyond Guilt and Atonement he explicitly addressed his German contemporaries who, as he put it, "in their overwhelming majority do not, or no longer feel affected by the darkest and at the same time most characteristic deeds of the Third Reich." ${ }^{17}$ More specifically, Améry struggled against a postwar Zeitgeist that he perceived as impregnated with "hollow, thoughtless, utterly false conciliatoriness." 18 In this situation, he not only refused to forgive: Améry explicitly denounced forgiving "induced by social pressure" as immoral, and he discordantly scorned those who were-all too early and easily in his opinion- "trembling with the pathos of forgiveness and reconciliation." As a rejoinder to common notions of the vengefulness of the unforgiving victim, Améry stated his conviction that a "loudly proclaimed readiness for reconciliation by Nazi victims can only be either insanity and indifference to life or the masochistic conversion of a suppressed genuine demand for revenge." 20

What accounts for this resistance to, and even disdain of, the advocacy and endorsement of forgiveness in the aftermath of the Holocaust? Evidently Améry's denigrations are directed towards certain pathetic, thoughtless, hollow, immoral ways of promoting or embracing forgiveness and reconciliation. Indeed, it is possible to read Améry as an illustration of what might be at stake when the talk of forgiveness becomes indistinguishable from escapist forgetting or unconditional acceptance. That is to say, the virtue of forgiving can easily be co-opted as a banner under which victims are actually urged to condone what happened-to move on, look ahead, bury the past and forget what, after all, happened so long ago. Thus, Améry's indignation could in principle be tied to a strong commitment to "genuine" forgiveness and to a belief that contemporary discourses compromised and perverted the real thing. Yet, even though Améry can be read as a strong challenge to advocates of forgiveness to reflect on the line between sentimental and sound forms of forgiveness-advocacy, it seems most certain that his contempt of and indignation for the advocacy of forgiveness was not due to a personal allegiance to forgiveness. Yet, and this is most interesting, the values and commitments that Améry was concerned about (and that he believed to be compromised by the cheap and thoughtless advocacy of forgiveness), are not necessarily incompatible with the values and

17. AMÉRY, supra note 16 , at xiv.

18. Id.

19. Id. at 65,72 .

20. Id. at 71 . 
commitments that inform at least some well-reflected approaches to forgiveness. ${ }^{21}$

To understand what lies behind Améry's attitude, we need to take a closer look at his essays in Beyond Guilt and Atonement, the chapter on "Ressentiments" in particular. It is impossible to do justice here to the complexity of Améry's reflections on these issues, but four reasons why his resistance to forgiveness was so vehement can be pinpointed: human dignity, recognition, accountability, and coexistence. These are the main conceptual points of the moral explanation offered by Améry to illuminate for his contemporaries just why he neither could nor would let go of his ressentiments or endorse their calls for forgiveness.

\section{A. Human Dignity}

Beyond Guilt and Atonement is, in part, an attempt to "rehabilitate" not just resentment, but the "man of resentment" - the common assumption that humanity and moral virtue are automatically behind displays of a willingness to forgive, reconcile, and "move on," whereas prolonged display of ressentiment and irreconcilability are the reflex of a morally flawed or deficient character. Trying to counter this picture, Améry articulates his own normative view on the proper allegiances of what he calls "the moral person," and the most central virtue invoked is the "moral power to resist." ${ }^{23}$ The sort of forgiving objected to by Améry was precisely promoted by pleas to accept that what happened, happened; that it was already long past, and that one would do well to look to the future rather than dwell on the irreversible past. According to Améry, to give in to such pleas would be unworthy of human beings qua moral beings. ${ }^{24}$ To give in to the social pressure and the implied attitudes of individuality, morality, and time would constitute a demeaning moral lapse. It is as if Améry asks, What kind of person would be able and willing to accept the call to forgive, forget, or reconcile in the given context (that is, under the circumstances of massive impunity and escapist forgetfulness)? As Améry viewed the situation, it would require a person willing to submerge his individuality into the needs and consensus of social opinion-a demeaning relinquishing of the moral experiences and demands of the individual. ${ }^{25}$ The ease with which the deindividualized person forgives might be celebrated from the perspective of a hasty societal interest in political stability and nation-building. Améry insists

21. See, e.g., GRISWOLD, supra note 4. For a position that combines vehement opposition to the advocacy of cheap forgiving as well as high praise of the "miracle" of forgiveness, see VLADIMIR JANKÉLÉVITCH, FORGIVENESS (Andrew Kelley trans., 2005); see also JEFFRIE MurPHIE, GETTING EVEN: FORGIVENESS AND ITS LIMITS (2003).

22. AMÉRY, supra note 16, at 64.

23. Id. at 72 .

24. Id.

25. Id. at 71 . 
upon a moral position that upholds the legitimacy of the voice of the individual in spite of its tense relationship with concerns about the social collective.

What Améry calls the "insensitive and indifferent person" is further characterized by his relationship to time and the healing it may bring about. ${ }^{26}$ Améry stipulates as unworthy the attitude that the future per se should be considered more important than the past, and that what is past should, simply qua past, be considered unimportant. According to Améry, this is an intolerable form of human subjugation - a moral defeat to the social and biological, or allegedly "natural," consciousness of time with its bias for the future. Equally incompatible with his notion of human dignity is the notion that one may allow the sheer passing of time to heal the wounds of the past. From within the "natural" perspective on time, forgetting and the kind of healing that time brings about may be suggested as a way in which to "get over" historical wrongs. The future-oriented person who allows "what happened to remain what it was [and] lets time heal his wounds" might be considered healthy from a therapeutic perspective..$^{27}$ But Améry retorts on moral grounds: "Man has the right and the privilege to declare himself in disagreement with every natural occurrence, including the biological healing that time brings about. What happened, happened. This sentence is as true as it is hostile to morals and intellects." 28

\section{B. Recognition}

Another reason Améry wanted to have nothing to do with what he called the "pathos of forgiveness and reconciliation" 29 had to do with his belief that it would do nothing to address the chasm between survivors like himself, on the one hand, and "the world which forgives and forgets" on the other. ${ }^{30}$ What was needed was an honest, if disturbing, confrontation with the Nazi past and its unrecognized implications for the present. To "forgive" or to be "conciliatory" in the face of continued denial and evasion would simply allow what happened to remain what it was. Améry was concerned that the rhetoric and pathos of forgiveness and conciliation would simply ratify or accelerate the general lack of recognition of what he called the "moral truth" of the Nazi past. ${ }^{31}$ What truth? The recognition, put all too briefly, that what had happened, or what was done, was utterly unacceptable and unjustifiable. Part of the reason Améry did not want to let go of his resentment was his belief that it (and with it, an impossible but essential demand that what had happened had not happened) harbored a truly moral understanding of what happened as absolutely unacceptable, as something with which there can be no reconciliation.

\footnotetext{
26. $I d$.

27. $I d$.

28. Id. at 72 .

29. Id. at 65 .

30. Id. at 75 .

31. Id. at 70 .
} 
Convinced that the urgent task was to uncover and to face the moral truth of what had happened, Améry insisted on the moral value of his resentments: "[M]y resentments are there," as he put it, "in order that the crime become a moral reality for the criminal, in order that he be swept into the truth of his atrocity." $" 32$

\section{Accountability}

The third point follows closely from the issue of recognition. According to philosopher Richard Wallace, resentment is distinguished by a connection with normative expectations. It is "caused by the belief that an expectation to which one holds a person has been breached." 33 What Améry expected, and what he held his contemporaries accountable to, was a moral response to the Nazi past, that is, an assumption of personal guilt or collective historical responsibility, or both. He brandished his ressentiments against denial, evasion, and cheap reconciliation. As expressed in and with his essays, his ressentiments maintained the stance of holding Germany responsible for its twelve years under Hitler: "In the midst of the world's silence our ressentiment holds its finger raised." 34 Thus, what he craved was not bloody revenge, but reassurance from the relevant moral communities that they could be trusted (again). ${ }^{35}$

\section{Coexistence}

Beyond Guilt and Atonement was published in the hope that it could "concern all those who wish to live together as fellow human beings." ${ }^{36}$ The preservation of resentment and the opposition to the rhetoric of forgiveness and reconciliation were related to a desire to be released from a deep sense of abandonment and loneliness. Améry held the world-and his German contemporaries in particular-to the demand of his ressentiments for an impossible undoing of the past. Evidently, he did not require satisfaction of this absurd demand, but he wanted his contemporaries to join his-the victim'smoral view of what had happened. Thus, although Améry refused any reconciliation with the past, his whole endeavor was aimed toward a reconciliation between people. In other words, in his mind, the condition of social reconciliation was a refusal of historical reconciliation. Améry struggled against an increasing sense of loneliness and abandonment-caused, in the first instance, by the persecution, torture, and evils of the Nazi past, but maintained

32. Id. at 70. For works stressing the significance of public recognition, see generally TRUDY Govier, Forgiveness And REVEnge (2002); ANDREW SCHAAP, POLITICAL RECONCILIATION (2005).

33. Richard Wallace, Responsibility AND THE MORAL SENTIMENTS 12 (1994).

34. AMÉRY, supra note 16 , at 78 .

35. For the conceptualization of resentment as tied to reassurance, see WALKER, supra note 4, at ch. 4 .

36. AMÉRY, supra note 16 , at xiv. 
and solidified by the subsequent history of denial and evasion of dignity, recognition, accountability, and true care for the other, that is, of coexistence.

\section{E. Loneliness}

"Ressentiments" ends on a bitter note, with Améry's articulation of deepseated mistrust about whether his call for accountability will be heeded. ${ }^{37}$ As he puts it, "the world which forgives and forgets" has sentenced him to loneliness. ${ }^{38}$ He feels condemnable as Shylock, "but already cheated of the pound of flesh too." ${ }^{39}$ Améry's ordeal, left with the mistrust and abandonment intensified by unanswered calls for reassurance and responsibility, is first fully expressed in the essay following "Ressentiment," the last essay of Beyond Guilt and Atonement. In stark contrast to his "moral daydream" of a restoration of human solidarity and responsibility, this essay now presents us with the point of view of a person who has almost resigned himself to a sense of inescapable abandonment and mistrust:

Every day anew I lose my trust in the world.... My neighbor greets me in a friendly fashion, Bonjour, Monsieur; I doff my hat, Bonjour, Madame. But Madame and Monsieur are separated by interstellar distances; for yesterday a Madame looked away when they led off a Monsieur, and through the barred windows of the departing car a Monsieur viewed a Madame as if she were a stone angel from a bright and stern heaven, which is forever closed to the Jew.... Without trust in the world I face my surroundings as a Jew who is alien and alone, and all that I can manage is to get along within my foreignness. . . . I was unable to force yesterday's murderers and tomorrow's potential aggressors to recognize the moral truth of their crimes, because the world in its totality did not help me to do it. Thus I am alone, as I was when they tortured me. Those around me do not appear to me as antihumans, as did my former torturers; they are my co-humans, not affected by me and the danger prowling at my side. ${ }^{40}$

III

\section{THE TEMPTATION TO FORgIVE: ESTHER MUJAWAYO}

From April to July 1994, more than 800,000 people (the majority of them Tutsis $)^{41}$ were killed in a horrifying genocide in Rwanda. Afterwards, the prosecution of all the genocidaires was simply impossible. In 2003, about 80,000 people accused of human-rights crimes were packed into jails, often in

37. Id. at 81 .

38. Id. at 75 .

39. Id. at 75 .

40. Id. at $94-96$.

41. Estimates for the total number killed in the genocide vary from 500,000 to more than 1 million. According to the official census report of the Rwandan authorities (quoted by Paul Kagame in April 2004), 937,000 Tutsi and Hutu opponents were killed. According to Alison Des Forges, around 500,000 people were killed. Alison DES Forges, LEAVE NONE TO TELL THE STORY: GENOCIDE IN RWANDA 15-16 (1999). For further details, see YVES TERNON, L'INNOCENCE DES VICTIMES: AU SIÈCLE DES GÉNOCIDES 140 (2001) (Fr.) and René Lemarchand, Rwanda et Burundi: génocides croisés, in ISRAEL W. Charny, Le livre Noire de L'Humanité: EnCyClopédie Mondiale des GÉnOCides 486, 486-87 (2001) (Fr.). 
insalubrious conditions, still waiting to come before the court. ${ }^{42}$ To face the concrete impossibility of any exemplar justice, various measures were taken: the liberation of 10,000 prisoners for health or age reasons, the increasing number of collective proceedings, and the launching of a new version of a traditional conciliation procedure, the gacaca. ${ }^{43} \mathrm{Up}$ to a certain point, the Rwandan response to the genocide seemed to illustrate the experience once articulated by Hannah Arendt, namely that there are certain crimes "[that one] can neither punish nor forgive." ${ }^{44}$ But the Rwandan authorities have not remained in Arendt's aporetic, stringently dubious, situation. Indeed, they explicitly called for forgiveness, presenting it as the key to the reconstruction of the national community. For example, since 2002 President Paul Kagame has explicitly encouraged forgiveness on a national level. ${ }^{45}$ In April 2006, at the twelfth commemoration of the Rwandan genocide, Kagame emphasized again the notion of forgiveness in underlining the importance to "confront the truth, to tolerate and to forgive for the sake of our future, to give the Rwandans their dignity." ${ }^{46}$

However, in spite of official policy and public pressure from NGOs and churches, the encouragement of forgiveness is rarely embraced among survivors. This section provides a closer look at some of the voices of resistance, Esther Mujawayo's in particular. ${ }^{47}$ Born in Rwanda in 1958, she is a sociologist and a psychotherapist. In 1994, she lost hundreds of relatives-including her mother, father and husband-during the genocide. She now lives in Düsseldorf, Germany, and works in the field of trauma therapy with refugees. She wrote about her experience in two books entitled Survivantes (2004) and La fleur de Stéphanie (2006). What one finds in these writings is not the often-praised voice

42. See Justice et Gacaca: L'experience Rwandaise et Le Genocide 75 (Françoise Digneffe and Jacques Fierens eds., 2003).

43. The gacaca court system started in 2002. In total there are 12,103 gacaca courts established nationwide, presided over by 169,442 inyangamugayo ("persons of integrity")-the local judges elected among the populace. The purpose of these courts is to gather survivors, witnesses, and suspects of genocide in order to establish the truth and to stop the culture of impunity by singling out those who actively participated in the killings. On the scope and limits of the gacaca courts, see Bert Ingelaere, The Gacaca Courts in Rwanda, in TRADITIONAL JustiCE AND RECONCILIATION AFTER VIOLENT CONFLICT: LEARNING FROM AFRICAN EXPERIENCES 25, 25-59 (Luc Huyse \& Mark Salter eds., 2008).

44. Hannah ARENDT, The Human CONDITION 241 (2d ed. 1998).

45. "The committed sins have to be repressed and punished, but also forgiven. I invite the perpetrators to show courage and to confess, to repent, and to ask forgiveness." Paul Kagame, President, Republic of Rwanda, Address at Urugwiro Village in Kigali (June 18, 2002), available at http://www.gov.rw/government/president/index.html. And later: "It is important that culprits confess their crimes and ask forgiveness to victims. On the one hand, the confession appeases their conscience, but above all these avowals comfort the survivors who can then learn, even though it is painful, how their close relatives were killed and where their bodies were abandoned." Colette Braeckman, Rwanda, dix ans après: Entretien avec Paul Kagamé [Rwanda, Ten Years Later: Interview with Paul Kagame], 103 POLITIQUE INTERNATIONALE 417 (2004) (Fr.).

46. Paul Kagame, President, Republic of Rwanda, Address at the Twelfth Commemoration of the Rwandan Genocide (Apr. 7, 2006), available at http://www.gov.rw/government/president/speeches 12006/07_04_06_genocide.html.

47. This story is a re-telling based on MUJAWAYO \& BELHADDAD, supra note 10. 
of the forgiving and conciliatory victim. To the contrary, even though Mujawayo endorses a gradual rapprochement between Rwandans in the long run, she clearly expresses her refusal to forgive, and talks of the inclination to forgive as a temptation. ${ }^{48}$ More than that, she talks about the interest in postatrocity forgiveness as an "obsession"-not on behalf of the survivors, but on behalf of the authorities, NGOs, and other agents of reconciliation. ${ }^{49}$

What accounts for such "negative" attitudes to the advocacy of forgiveness? Of course, a comprehensive exploration is impossible here, but focusing on three different and partly successive reactions depicted by most of the Rwandan survivors will to some extent illuminate what lies behind this kind of resistance. The first is summarized by a single word: silence. The second is a strong refusal to forgive. The third, more global, one is a distancing from any "politics of reconciliation." Each of these reactions indicates the limits of a forgiveness presented as a miraculous formula for reconciliation.

\section{A. Silence}

Although questions of forgiveness loom large in current discourse on reconciliation, the issues faced most urgently by genocide survivors do not always or necessarily involve either forgiveness or anger or its overcoming. Instead, the response to past atrocity can engage deep sadness, fear, loss of trust and hope, and other emotions that might lead to silence rather than to calls for justice and accountability. In her first book, Esther Mujawayo depicts the initial reaction of most of the survivors after the genocide: "No one... explicitly asked us to be quiet, [but] we have immediately felt that we had to [be]."

The sheer difficulty of finding proper words, as well as listeners, is not the only reason for this first reaction. Many survivors decided to be silent because they felt guilty, ashamed, or afraid. The paradoxical guilt experienced by many of the other survivors around Esther Mujawayo resulted from the fact that they-and not the others-survived, that they could not save their loved ones, or that they could not find their loved ones' bones. As for the shame, this feeling is often linked with the violence, especially sexual violence, that they underwent. Even though eighty percent of the women who survived were raped, the reality of this specific violence is still a taboo. ${ }^{51}$ According to representatives of the Association of Genocide Widows (AVEGA), "[T]he rape, you bear it silently, in such a shame that no one could even imagine. But you, you always feel like a stink inside your body and a grime that itches your skin. ${ }^{\prime 53}$ This shame and constant humiliation-reinforced by the stigmatisation

48. Id. at 17 .

49. Id. at 127.

50. Esther Mujawayo \& Souad Belhaddad, Survivantes: Rwanda, Histoire d'un GENOCIDE 20 (2004) (Fr.) (translation by authors).

51. MUJAWAYO \& BELHADDAD, supra note 10, at 196.

52. See Avega Agahozo, http://www.avega.org.rw/English.html (last visited Mar. 18, 2009).

53. MUJAWAYO \& BELHADDAD, supra note 50, at 201. 
of any one Tutsi, systematically identified with a cockroach during the genocide ${ }^{54}$-are so deep that the roles seem reversed: "The survivor is ashamed to meet the killer of his close relatives; he [the survivor] is the one who is afraid, who feels humiliated to see the perpetrator walking like that. He feels so guilty." ${ }^{, 55}$

This sense of the survivor's guilt and shame can be associated with another cruel inversion of the roles during the genocide-when the victims themselves asked for forgiveness from their perpetrators. Several witnesses explained that, in front of the Interahamwe, victims were indeed asking for forgiveness in order not to be tortured for too long. ${ }^{56}$ The fear expressed by the survivors can be explained by various elements: angst about not being believed, anxiety in front of recently liberated perpetrators, and a general feeling that they would be bothering everybody. With the "un-listenable" mingling with the unspeakable, both tendencies imply a loss of confidence in the world and the loss of any sense of personal safety. Facing these extreme difficulties, the Rwandan victims have to make an immense effort to testify in front of a sometimes-hostile gathering, to express publicly tragic facts (above all, sexual violence), to denounce neighbors, or even members of their own family. As Mujawayo noticed, in these circumstances forgiveness is not the primary concern of the survivor. ${ }^{57}$ Arguably, this kind of "distancing" from the entire issue of forgiveness is not an example of resistance to forgiveness in the sense of active and focused opposition, like that of Améry. But the situation is prone to feed into a kind of loathing and disdain that is as significant as the more explicit forms of opposition. Consider for example this remark by Innocent Rwililiza, as quoted in one of Jean Hatzfeld's books on post-genocide Rwanda:

Actually, who is speaking about forgiveness? Tutsis, Hutus, liberated prisoners, their families? None of them, it is the humanitarian organisations. They import forgiveness in Rwanda, and they wrap it in dollars to convince us. There is a Forgiveness Plan as there is an Aids Plan, with meetings of popularization, posters, little local presidents, very polite Whites in cross-country and turbo vehicles.... We, we speak about forgiveness to be well considered and because subsidies can be lucrative. But in our intimate talks, the word "forgiveness" is strange, I mean constraining.

\section{B. Clear Refusal to Forgive}

Beyond this first reaction, Mujawayo insists on her resistance to any kind of forgiveness toward perpetrators. She says,

$[\mathrm{T}]$ he more I think about that, the more I ignore what forgiving means, except this mini-settlement that I make with myself to hold out[] for a pretended moral

54. Louis Bagilishya, Discours de la négation, dénis et politiques, in L'Histolre TrouéE: NÉGATION ET TÉmOIGNAGE 733 (Catherine Coquio ed., 2004) (Fr.).

55. Speciosa Mukayiranga, Sentiments de Rescapés, in L'Histoire TrouéE: NÉGATION ET TÉmoignAGE 783 (Catherine Coquio ed., 2004) (Fr.) (translation by authors).

56. HATZFELD, supra note 12, at 198.

57. MUJAWAYO \& BELHADDAD, supra note 10 , at 127.

58. JeAn HATZFELd, LA STRATÉGIE DES ANTILOPES 25 (2007) (Fr.) (translation by authors). 
appeasement, to 'win' against hatred .... Today, as the years go, I accept better, I finally accept that, no, I will not forgive."

This position relies on two main reasons: on the one hand, the lack of energy to adopt an empathetic view of perpetrators, and, on the other, a deep discontent with what might be called a "cheap" repentance.

Speaking about the killers, Mujawayo explains that empathy must follow a return of her energy:

I don't want to understand them, at least, not yet. I want to proceed step by step: within ten years maybe. I don't want to understand... I say to myself that some people are paid for that, for understanding the killers-politicians, humanitarian staff, right-thinking people... all those whose work is to get into contact with criminals. Myself, I don't need that. I don't want to understand them and I don't want to excuse them. They did it ... and I want them to pay for that and not to sleep soundly. ${ }^{6}$

This refusal to understand the "other" to some extent results from the immense fatigue felt by survivors who have so many other priorities in the current Rwandan context. Before thinking about the potential scope of empathy, Mujawayo wants "some bread for those who survived." ${ }^{61}$ However, apart from the inappropriate character of any "duty to understand," not deny the humanity of each Rwandan, including perpetrators: "Yes, there is a human touch in each of us, and therefore in each of them, and who knows what we could have done in their place." ${ }^{63}$

Mujawayo's attitude seems to be characterized by a constant effort to take into consideration the ambivalence and complexity of the situation. Underlining the loneliness that goes with the experience of victims, she does not expect any kind of revenge in order to appease this feeling. Nonetheless, she maintains that victims have the right not to be above resentment. Being a psychotherapist, she does not feel any guilt when she faces her own resentment. Taking lucid account of the limits of her powers, she knows and she accepts that, for most survivors, full empathy would be unattainable and even counterproductive. Like Améry, she seems to consider resentment as a deeply human attitude. ${ }^{64}$

The second reason for survivors' resistance to forgiveness is that forgiveness does not make sense when perpetrators do not express any remorse. According to Mujawayo, "[M]ost of the killers do not ask forgiveness, they say sorry .... Or they ask it with the certainty that this request . . . inherently merits a positive answer." ${ }^{65}$ To her, the notion of forgiveness is not the same for the killer and the survivor. For the perpetrator, it represents a potential reduction of sentence, whereas for the victim it appears either as something beyond reach or as a

59. MUJAWAYO \& BELHADDAD, supra note 10 , at 126.

60. Id. at 87.

61. Id. at 189 .

62. Id. at 87 .

63. Id. at 120 .

64. For an elaboration on this point, see Arne Johan Vetlesen, A Case for Resentment: Jean Améry Versus Primo Levi, 5 J. HUM. RTs. 44 (2006).

65. HATZFELD, supra note 58 , at 87. 
sacrifice. Against this background, Mujawayo wonders, "To forgive whom in fact? The one who writes you his letter of repentance?" This question denounces the quasi-administrative letters written by perpetrators in order to be liberated as soon as possible. To Mujawayo, these documents at best mimic a true acknowledgment of responsibility and a genuine address to the survivors. In La Fleur de Stéphanie, she gives an example of the hundreds of similar letters sent to survivors:

Musange, province of Gitarama

Object : [T]o ask forgiveness [of] Nyirakanyana Madalina's family

I, N.V., son of K., I am writing to Nyirakanyana Madalina's family, asking them forgiveness because I was one member of the group that took her from M.P.'s house (a neighbour)... . This group was directed by M.F.... [a list of 11 members follows]. These are those with whom we took her together to the river Nyabarongo but I, at that moment, I stopped on the riverside. Then, I ask you, the members of Nyirakanyana's family, forgiveness; to the State, I also ask to forgive me, to God too I ask forgiveness, and I hope that you will forgive me as well. Peace of God with you".

[Following is a signature, a name, and fingerprints.] A last sentence specifies: "This letter is notified to the gacaca coordinator of M[.] Muhanga.” ${ }^{66}$

To Mujawayo, this kind of statement, always identical (same phrases, same structure) is almost indecent because it does not express any regret or any personal responsibility: everyone is hiding his own behavior behind "the group as such." ${ }^{67}$ Many survivors confirm that not a single prisoner came and expressed remorse for what he did. In some cases, prisoners decided to confess their crimes, but they did it in a mechanical way, and even required the victims' forgiveness-most often taken for granted. There are pressures in favor of forgiveness all around (from official authorities, churches, and NGOs) $;{ }^{68}$ survivors discredit mainly what they consider as only a pretense of forgiveness.

The absence of authenticity is apparent in many gestures leading theoretically to forgiveness: "Humanitarian organisations ... spend millions of dollars in order to make us forgiv[e] and bind each other by friendship. But survivors do not want to bargain their word against little compensations. ${ }^{\prime 69}$ This account likewise illustrated the hollowness of the victim's forgiveness in response to the hollowness of the perpetrator's request for the same:

Two people came at home to ask me for forgiveness. They did not come willingly, but in order to avoid the prison. It is difficult to explain to a father how one has cut his daughter or for the father to ask these people how they have cut her. Then, we did not say anything but polite phrases .... To listen to them or not to listen to them was the same[.] I listened to them in order [for] them to go away quicker[,] letting me alone with my grief. When they left, the persons added that they had been kind with me since they missed me in the marshes. Me, I pretended to thank them. ${ }^{70}$

\footnotetext{
66. Id. at $128-29$.

67. MUJAWAYO \& BELHADDAD, supra note 10 , at 127 .

68. HATZFELD, supra note 58, at 25.

69. Id. at 101.

70. Id. at 104 .
} 
This strategy, used largely by criminals to avoid too many years in prison, creates an overwhelming sense of injustice in the victims. In some cases, as the former prisoner Elie Mizinge explains, perpetrators even regret not having "finished their job. They blame themselves for negligence, more than for spitefulness.... Waiting to start again." " However, the external pressure is perceived as so intense that some survivors tend to internalize a certain obligation to forgive. As another victim said to her former perpetrator, "The government forgave you and I cannot refuse it to you." "'2 Similarly, several other survivors explain that they agreed to forgive because the "power"the Church-asked them to do so. ${ }^{73}$

\section{A Global Distancing from any "Politics of Reconciliation"}

In Rwanda, as well as in other places, like South Africa, forgiveness has been publicly encouraged as the only, or at least as the most important, condition for reconciliation. ${ }^{74}$ Unsurprisingly, the resistance of many victims to public pleas for forgiveness can seep into a more general animosity against the process of reconciliation. Many survivors denounce the so-called "politics" or "ideology" of reconciliation:

Reconciliation. This word became unbearable to me and to most of the survivors who[m] I know. To me, it is even perfectly indecent after genocide...." To reconcile," as it is written in the dictionary, consists in making people at odds agree again... Do I have to consider that what happened in Rwanda between April and July 1994 is the product of a dispute, a quarrel, a disagreement[,] and therefore that it would not be understandable not to reconcile? Do the people who use this word all the time realize that its meaning is fundamentally simplistic?

Moreover, the public advocacy of forgiveness and reconciliation is permeated with promises of healing, peace, and harmony. At this juncture, forgiveness and reconciliation can take on the quality of a temptation, a lure of redemption. The words of Mujawayo on this point are univocal:

I really hope that I will not give in to ... the "national reconciliation" camp... To have a grudge against somebody requires an important mental resistance: you are thinking about it all the time and this feeling consumes you so much that, just to appease it a little bit, you sometimes find yourself having the temptation to forgive. If, furthermore, governmental politics presents forgiveness as a national priority ..., I do fear the easiness of such project: all of us would be beautiful, we would finally have become nice, everything would be well cleaned and then, that would start again! But what would start again in fact? ${ }^{76}$

71. HATZFELD, supra note 12, at 198.

72. Gakenke \& Umutara, Penal Reform International, Rapport de Synthèse de MONITORING ET DE RECHERCHE SUR LA GACACA (2005), available at http://www.penalreform.org/ resources/rep-ga7-2005-pilot-phase-fr.pdf (translation by authors).

73. HATZFELD, supra note 58, at 19.

74. Cf. Brudholm, Forgiveness after Mass Atrocity, supra note 14.

75. Immaculée Mukarwego, quoted in Colette Braeckman, Les fantômes d'Immaculée hantent toujours les collines, LE SOIR (Fr.), Apr. 7, 2004 (translation by authors).

76. MUjAWAYO \& BELHADDAD, supra note 10, at 17. 
Beyond this general resistance to any official "politics of reconciliation," Mujawayo is ready to conceive a gradual rapprochement, on a people-to-people level, among Rwandans. If she refuses to forgive, literally, she does not totally reject the concept of reconciliation "because there is no other possible choice."

All those I met in Rwanda, until the survivors working on the field,... never think about forgiveness.... However, all of them work in favour of a reconciliation. Because to reconcile does not mean to forgive. To take up with neighbours again, starting with the ability to greet each other, is important for all the reasons that I have already emphasized: our culture cannot be conceived without these traditions, these rituals.

The record of Esther Mujawayo manifests the unavoidable tension between the need to look forward and the absolute necessity of respecting the intimate experience and personal pace of each survivor. In this regard, the challenge is paramount. As Mujawayo emphasizes, "[T]his is not the end of the genocide that really stops a genocide, because inwardly genocide never stops." ${ }^{\text {"79 }}$ The same experience is echoed in the words of another: "The survivor remains inconsolable. He resigns himself but he remains in revolt and powerless. He does not know what to do, the social environment does not understand him, and he does not understand himself either." ${ }^{\circ 0}$

\section{IV}

\section{CONCLUDING REFLECTIONS}

Persons who refuse to forgive are often and easily seen as somehow exemplifying various moral failures (of judgment understanding, et cetera) or psychological (and thus more-or-less understandable) shortcomings. Yet, although the refusal to forgive can be testimony of self-righteous rigor, vengeance, or a reduction of wrongdoers to what they have done, it is essential that the discussion of forgiveness and its alternatives take more seriously the possibilities and sources of various kinds of more or less legitimate resistance. The cases of Jean Améry and Esther Mujawayo deviate from the common "imaginaries" of the agents of unforgiveness. Neither of them is consumed by hatred or out for bloody revenge: they suffer and a tempered measure of rage suffuse the writings of Améry in particular, but their reasoning and aims are not deluded, self-preoccupied, or morally demeaning. Moreover, though Améry and Mujawayo might be exceptions in some regards, we surmise that there are many other cases of similar sobriety and complexity. Consider, for example, the case of Primo Levi (who repeatedly stated that he did not forgive), Vladimir Jankélévitch, or a host of other examples from Rwanda and South Africa.

One of the important "lessons" emerging from these and similar cases is the inadequacy of an overly individualized focus on the survivor and her personal

77. Id. at 130 .

78. Id. at $130-31$.

79. Id. at 197.

80. See Mukayiranga, supra note 55, at 777. 
or community issues. Whether one thinks of Améry or Mujawayo, it is impossible to account for their attitudes without attention to their perceptions of their social contexts and, in particular, the attitudes of their communities. After mass atrocity, the preservation of resentment or resistance to forgiveness might be largely dependant on perceptions of the attitudes prevalent among entire social groups, authorities, and so on. In Mujawayo's case, the relevant others are not only the majority of criminals and their families-who rarely expressed any kind of remorse-but also the Tutsis who arrived in Rwanda after 1994 and who are therefore not still-wounded survivors. Even though they of course do not deny the genocide, they are preoccupied mainly with the need to concentrate on building the future. To some extent, they seem to be bored by the victims' expectations or claims. ${ }^{81}$ Another significant point has to do with the nature of victims' resistance to forgiveness. Whereas advocates of forgiveness tend to represent or imagine opposition in the form of the total refusal to forgive, the examples from Rwanda testify to more-reasoned and conditiondependent forms of resistance. One will not forgive because of the absence of repentance (or because of the cheap and hollow way in which a perpetrator is encouraged to "forgive"), because of the urgency of other issues, and so forth.

Vladimir Jankélévitch once observed that forgiveness can be recommended in such ways as to make people disgusted with it. ${ }^{82}$ This is an important point, because it indicates the reason why victims and survivors in many different places respond negatively to social or official encouragements of forgiveness after mass atrocities. Yet what if forgiveness is recommended in proper and respectable ways, in a way that avoids placing pressure on victims to forgive, that stops short of pathologizing or diminishing unforgiveness, and that is receptive to legitimate alternatives? Even then, it is highly questionable whether reconciliation is well served by being closely tied to an advocacy of forgiveness. Forgiveness overburdens reconciliation insofar as the latter is thought to build on a general endorsement of the former. Unless drastically redefined to suit political processes, forgiveness should perhaps be respected as an anomaly - a sometimes highly admirable and laudable gesture, but something that should, as Jacques Derrida put it, "never amount to a therapy of reconciliation," ${ }^{83}$ something that "must remain a madness of the impossible." ${ }^{84}$

81. MUJAWAYO \& BelHAdDAD, supra note 10, at 20; see Mukayiranga, supra note 55, at 782-83.

82. JANKÉLÉVITCH, supra note 21, at 55.

83. JACQUES DERRIDA, ON COSMOPOLITANISM AND FoRgIVENESS 41 (Mark Dooley \& Michael Hughes trans., 2001).

84. Id. at 39. The viability and propriety of forgiveness (variously understood) in the political realm has been debated intensely in recent years. See generally PETER DIGESER, POLITICAL Forgiveness (2001) (offering a secular and public concept of forgiveness); GRISWOLD, supra note 4 (including a very critical discussion of the political use of forgiveness); THE POLITICS OF PAST EVIL (Daniel Philpott ed., 2006) (including theological justifications of political forgiveness). 